\title{
SURVEY METHODOLOGY AND GEOMETRICAL ANALYSIS OF LATE GOTHIC ARCHITECTURE IN SARDINIA
}

\author{
Claudia Pisu \\ PhD Lecturer, Department Civil, Environmental Engineering and Architecture, University of Cagliari, Italy \\ claudiapisu@gmail.com
}

\begin{abstract}
The work proposes a new approach to study the Sardinian late gothic architecture, so far limited mainly to the historical aspects. The intent is to study such architectures from different points of view, starting with historical known data, enriching them with information concerning the shape and the geometry that generated it. I believe that any construction that shows continuity encloses a project design and a geometric construction, then the detailed knowledge of dimensional and material aspects allows a comparison between similar elements to highlight relationships and differences between buildings and construction elements. The relation of proportion in the design of constructive elements such as doorways, windows, etc., can supply important information on the design choices of the builders, who certainly drew from a vocabulary of coded shapes and pre-established sizes, well known within the Gothic builders. The study takes as examples the late Gothic portals of the Sardinian churches. I intend to assess whether there are pre-established rules, which go beyond the stylistic comparisons and extend the cognitive framework on the architecture they belong.
\end{abstract}

Keywords: Late-gothic architecture, Surveying, Design analyses, Geometric analysis, Proportional analysis, Representations of architecture.

\section{INTRODUCTION AND RESEARCH AIM}

Sardinia, from the Fourteenth to the Eighteenth century, was part of the crown of Spain, and also on its territory the gothic building culture developed and consolidated in repeatable encoded forms which affected both the civil and religious architecture. The late Gothic constructive types appeared in Sardinia in the Fourteenth century and reached the maximum spread between the Fifteenth and Seventeenth centuries. During this period, groups of local manufacturers reworked, according to their taste, shapes acquired from Spain, particularly Catalonia. Portals, along with the vaults and the rose windows, are certainly among the strongest characteristic features of religious buildings in Sardinia. Notable examples of these elements are found throughout the island. [1]

Despite the fact that Mediterranean regions exhibit many specific achievements in Gothic architecture [2], the study of Gothic architecture was developed mainly for buildings of the Central European region, which belongs to France, Germany and Great Britain [3]. The architectures of Sardinia built between the Fifteenth and Seventeenth centuries are part of the Mediterranean Gothic, and can be placed in the vein of the Spanish late Gothic. They are still largely unknown, especially those located in minor contexts [4]. This study aims to deepen the knowledge about some special features in the Sardinian late-Gothic buildings. It is part of a wider research, which covers the entire spectrum of late Gothic architecture of
Sardinia, and that embraces a fairly wide period, coinciding with the belonging of the kingdom of Sardinia to the crown of Aragon and then to Spain In the context of this research, many cultural and historical information were acquired and analyzed; they were also used to address the proposed study on the portals [5].

Much has been said by historians regarding some of these architectures [6], however, a systematic study that takes into account metric and materic aspects is only at the beginning. Surely the most studied buildings are the churches that stand out, in size and completeness of the work, in the panorama of island architecture. There are surveys of many of these buildings, performed almost exclusively for the restoration project and stored at the Superintendence. Very few of these surveys were published, and only a small number takes into account the geometric and dimensional relationships between the parties and develops hypotheses about the stratigraphic chronology of the structure. We were able to also note that, within the operations of drawing and survey in most cases the elements of detail are neglected and considered as a corollary of the whole. They are used as tools of stylistic comparison with particular attention to the decorated elements, and also in this case, the geometric and dimensional comparison is neglected compared to the formal one. These aspects, however, deserve more attention because they are often the only vehicle for understanding this type of architecture as widespread as poorly documented. 


\section{OBJECT OF THE STUDY}

The late Gothic church of Sardinia has a very simple planimetrical scheme. It is set on a rectangular plan, with cross vaulted (simple or stellar vault) presbytery and cross vaulted chapels along the aisle [7]. Access to the church in most cases is done through a single opening, a portal. In the oldest system, the portal with the rose window was the only element that gave light to the aisle, since small round windows of the side chapels were not always present. The portal is inserted into a facade which generally has these characteristics: flat, rectangular shape bounded by buttresses (which actually does not have a static function as the roof of the hall is gabled), bell tower on the right side. Many of the late Gothic churches found in Sardinia, have been modified and expanded over the centuries, so the still preserved original features are reduced to a few parts. What was most frequently retained is the portal: for this reason it was considered as a valuable source of study for several comparisons.

The study highlights a series of different forms of portals that can be attributes to the period between the fifteenth and sixteenth century. The examples are many and still widely spread throughout the island. Here I propose some results of a research project that led to the creation of a database in which the buildings have been identified and divided by type of portal [8]. The database, divided by municipalities, contains the name of the churches with the dating and the late Gothic elements still present in both the exterior and the interior: the vaults, the bell tower and facade elements as the rose window, the flat facade and the portal. The portals were then divided into several distinct types, mainly according to the geometric shape of the opening: pointed arch, rounded arch, arch with three centers, architrave, or other types not related to previous ones, characterized by a multi-linear geometry, which, in some cases, it resolves over a flame arch [9].

Table -1: Buildings with gothic characteristic so far surveyed

\begin{tabular}{|l|l|l|}
\hline $\begin{array}{l}\text { Number of surveyed buildings that have late- } \\
\text { Gothic characteristics (vaults, chapels, rose } \\
\text { windows, etc..) }\end{array}$ & 136 \\
\hline $\begin{array}{l}\text { Number of buildings with late Gothic or } \\
\text { Renaissance portals. }\end{array}$ & 73 \\
\hline
\end{tabular}

Table -2: Types of late Gothic portals

\begin{tabular}{|l|l|l|}
\hline Type of portal & $\begin{array}{l}\text { Number of } \\
\text { documented cases }\end{array}$ & $\begin{array}{l}\text { total } \\
\text { towns }\end{array}$ \\
\hline pointed arch & 29 & 26 \\
\hline round arch & 26 & 26 \\
\hline architraved & 9 & 9 \\
\hline arch with three centers & 5 & 5 \\
\hline other & 4 & 4 \\
\hline
\end{tabular}

In the study I take as examples the portals with pointed arch. They are the most common of late Gothic architecture in Sardinia. Among the surveyed buildings, reported in the table [10], I considered two examples, the most representative for the shape, decorations and materials of construction, located in different regions of the island where there are the greatest number of examples, in order to illustrate the method of comparison. I want to understand the differences and similarities developed in the two geographical areas. I conducted a detailed analysis on the portals of the churches of San Giorgio in Sestu (Cagliari) (XVI century) and Sant'Andrea in Ula Tirso (Oristano) (XVI century). Albeit in different state of preservation, they appear similar in many aspects: the rectangular opening is framed by pilasters with cylindrical capitals, and surmounted by a pointed arch with eyebrow. Ashlars of the lintel are always processed to form a protruding molding that emphasizes the rectangular aperture, separating it from the decorative pointed arch.

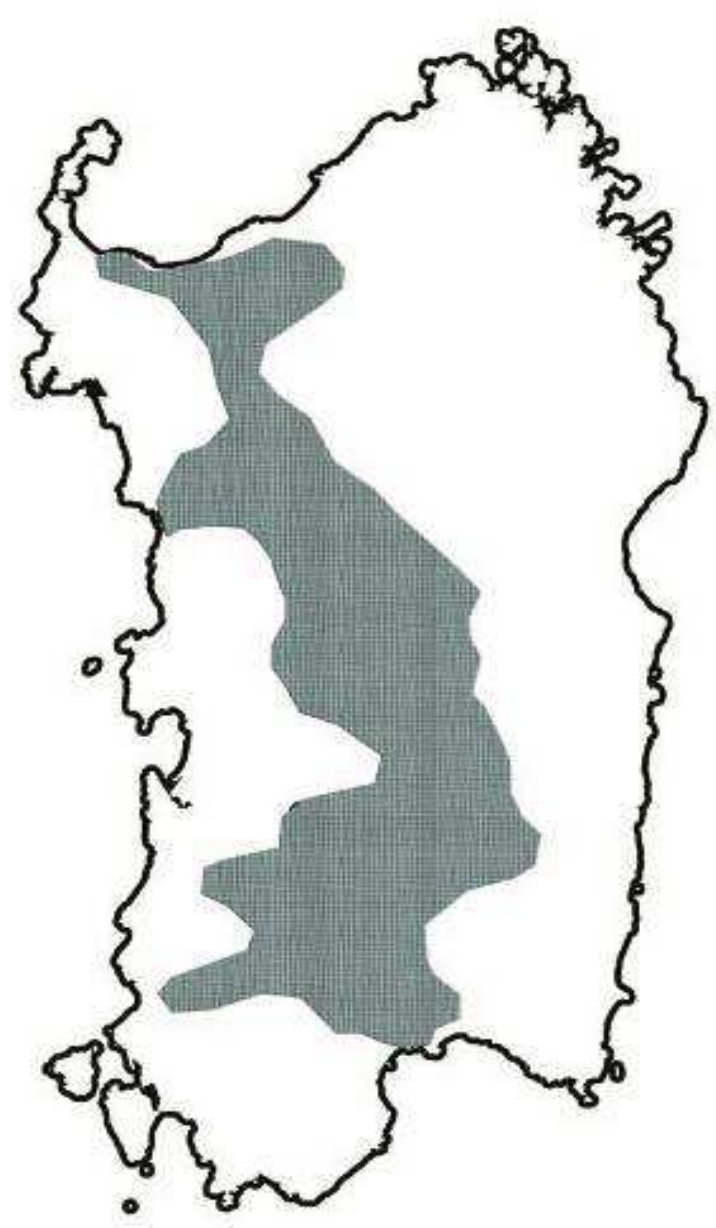

Fig -1: Area of the island where there are the greatest number of portals and building with late gothic characteristics 


\section{METODOLOGY OF STUDY}

I used a method of study that consists of a dual analysis concerning the design and geometrical and proportional analysis, two fundamental aspects in the investigation and understanding of architecture. I wanted to place emphasis on the need for an analytical and critical approach in the collection of metric and material data of the objects to document, and show how the apparent homogeneity of shapes and decorative choices actually hides distinctive signs and marked differences between objects. I combined the geometrical analysis, the study of proportions and the search for a module also through the study of the units of measure, tools that are used frequently in the analysis of architecture [11].

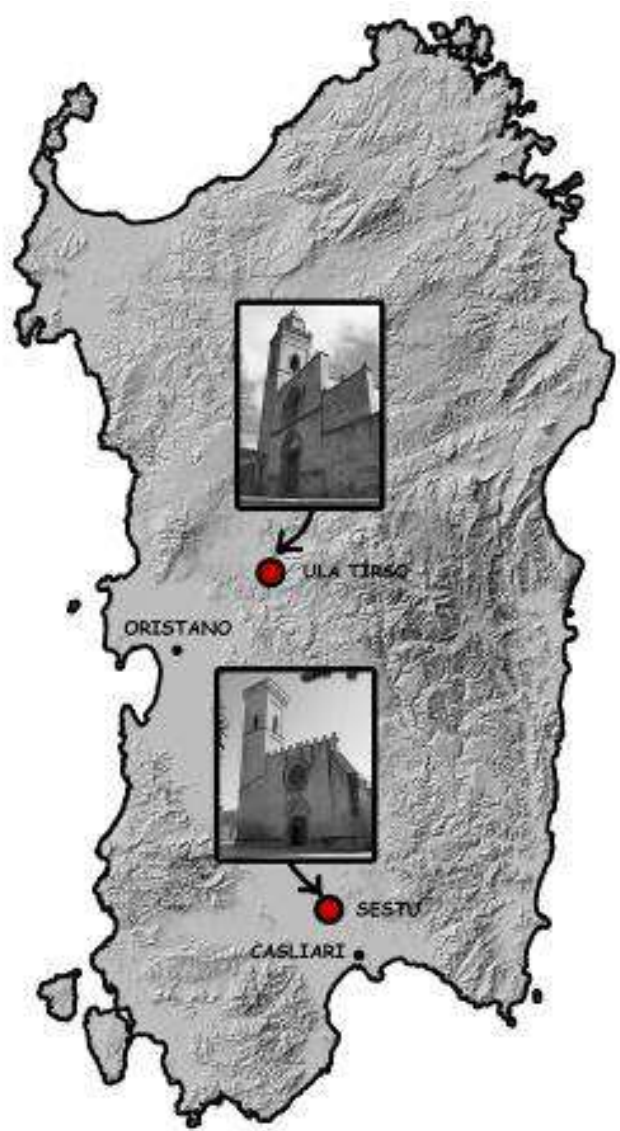

Fig -2: Localization of portals studied

\subsection{Measuring and Survey}

The study and understanding of architecture occurs through the architectural survey and the resulting graphical summary of what has been observed, measured and examined. Measuring an architecture means performing an operation that will lead to a full understanding of the work in its entirety and in its details, capturing the dimensional and constructive values, but also formal and cultural ones. The first approach consists in a careful examination, during which, the process of observation and direct measurement reveals the intrinsic characteristics of the building. Such a read operation, together with the historical and archival studies, represents the preliminary stage of the documentation. What really exists is synthesized by the drawing, and then deepened by historical and stylistic studies. Ideally these operations should be performed in parallel, since the historical analysis provides the critical means, and the graphical analysis the objective one [12].

From time to time, the methodology evolves and adapts to the problems that exist in the particular case. For each survey, a new look, a new procedure, a new technology adds to the already encoded and consolidated methodologies [13].

This way of working, which adds to the cognitive and documentary operation, the interpretative ones, elevates the purely technical survey to research activities [14].

The adopted methodology is mainly that of the direct survey, carried out with simple measuring instruments such as meter, plumb, set square, telescopic poles and the help of the laser distance meter. To complete the measurement operations, we conducted a photographic survey functional to photomodeling. This kind of survey was very useful in the study of the moldings. [15]

In the first phase, I carried out the preparatory sketches, upon which I have written down the measurements. In this phase I have tried to bring the measured elements in simple geometric shapes, in order to primarily study the shape and size without going into detail of the decorations. For example, I studied the geometric shape that generates capitals, and the dimensions and proportions of this shape compared to the other elements constituting the opening. The restitution of the drawings was performed using CAD and, for each portal, I proceeded to the schematization of the elements that compose it.

\subsection{Graphical Analysis}

The graphical analysis allows to make a comparison based on geometry and size [16] [17]. These comparisons are made between the sizes and shapes. The study, however, is not free subjective interpretation, typical of the surveying tasks [18]. In fact, when you draw up the draft of the operations of detection, you define the interpretive basis, and, once chosen, it is repeated in the same for all objects to be compared. I used a procedure for the determination of possible affinities, similarities, differences, peculiarities of the various portals, using a repeatable method divided into few stages. These steps are applicable, with the appropriate corrections and adjustments, to other similar cases and/or items of greater or lesser size. The study aims to establish a starting point for further investigations on the subject that could take off by extending the analysis to other regions of the island where the portals have similar characteristics and well-marked variations. I have analyzed the proportional relationships between the different parties and verified whether the 
composition of the opening responds to recurring ratios in architectural design. I first considered the golden ratio, a point of reference in many eras. I also took into account the different proportions derived from the application of modular mesh. In fact, the Gothic builders frequently based their compositions on the architectural relationships between simple polygons such as triangle, square and circle [19].

\subsection{Experimental Data and Results}

As there is a wide variety of shapes and decorations, and portals with pointed arches are ultimately all different from each other, there are some common rules that can be instantiated and provide a single criterion of reading. I found some differences both in the proportions of various elements, both in the use of moldings and ornaments, but the constituent parts are always the same. The opening is of rectangular shape bounded at the sides by molded piers, which rest on truncated cone bases, where still appreciable, and ending in capitals of variously decorated with cylindrical shape. The pointed arch is set on top of the capitals. It is also molded and with eyebrow arch ending in two corbels entirely similar to the capitals in shape and type, but of larger dimensions. In some cases, as well as in those analyzed, the upper part of the opening is constituted by a lintel, overhung by a rectilinear framework that intersects the arch height of the capitals. The Sestu portal has some side shelves for further decoration of the lintel, as well as other in nearby centers Assemini, Cagliari, Uta and Villasor. We also noticed some differences, regarding, for example, the number of bands in the molding, usually composed of three elements. In the examined cases, the Ula Tirso portal has a decorative band in more than Sestu, ending in a capital square. Generally, the capitals of the outer ring are of larger size than the others and may be located in correspondence of the latter, as in the case of Ula Tirso, or in a position where the lower part of the largest coincides with the upper one of the smallest, as in the case of Sestu.

Not all portals have the wainscot decorated connected to the base, element present in different forms, both in Ula Tirso that in Sestu.

During the survey operations, I was able to verify the conservation status of portals, noting that no original shape is perfectly preserved: in certain cases, some parts are very worn and therefore not valuable, in other cases, whole elements have been replaced, such as the threshold, the abutment, the base. The upper part where there are the capitals, the lintel and the arc, are completely conserved in nearly all cases. The study of geometry and proportion of the portals is strongly affected by their condition. In the examined cases, it is plausible to think that all the elements are still the original ones, including the threshold. Usually this element is the most subject to variations due to superelevation of the pavement both inside and outside the building. The state of wear depends strongly on the type of stone of which the portals are made: in the case of Ula Tirso it is volcanic rock commonly known as "trachyte", which has a porous surface with a tendency to flake; in the case of Sestu it is calcare, commonly known as "stone Canton", that does not have excellent mechanical properties [20].

Starting from these premises, I conducted the geometric and dimensional comparisons between the two examined cases, in order to see if their design is related to proportioning methods commonly used by the Gothic builders, and based on precise rules of geometry and mathematics. First, the comparison immediately highlights the difference in size, certainly related to the total size of the elevation and, more generally, of the building: the portal of Sant'Andera of Ula Tirso measure over a meter higher than that of San Giorgio of Sestu.

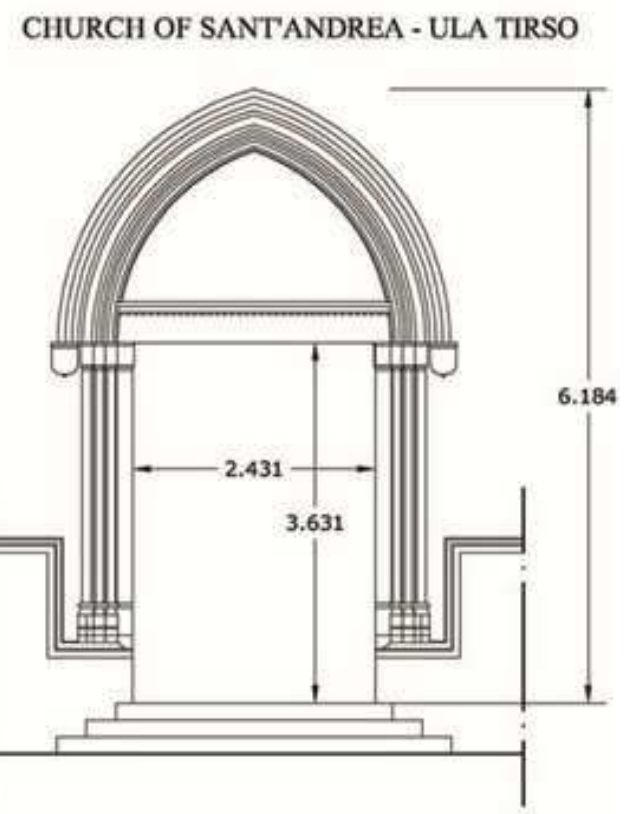

CHURCH OF SAN GIORGIO - SESTU

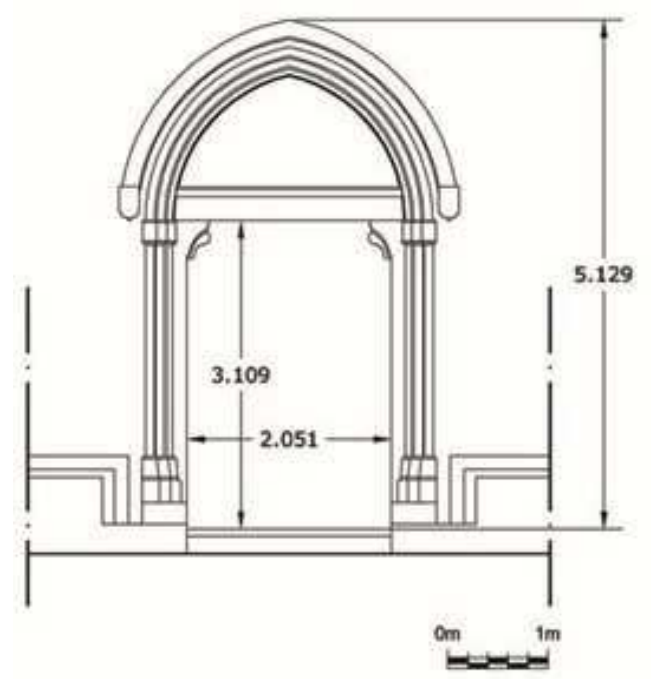

Fig -3: Comparison between dimensions of studied portals 
I investigated whether the works were designed using the Catalan units or the Sardinian ones. In particular, there were two measures called "Canna": that of Barcelona corresponds to $1.555 \mathrm{~m} \mathrm{[21]}$, and the Sardinian one corresponds to 3.148 $\mathrm{m}$. The Canna of Barcelona is about half of the Sardinian one, but the submultiples are different, the first is divided into 8 spans while the second in 12 .

In Sardinia was also used another unit, the small span of $0.2333 \mathrm{~m}$ derived from the "Destre" of Barcelona to $2.796 \mathrm{~m}$, divided into 12 parts. In the seventeenth century, in different parts of the island, the builders also used the span of $0.2796 \mathrm{~m}$, corresponding to $1 / 10$ of the "Destre" of Barcelona [22].

I compared the measures of the portals with the units of measurement, in order to verify if there is a congruence with one of these. In the portal of Sestu the main measures and all elements are proportioned according to the span of Bacellona. In the Ula Tirso portal I found a congruence of the main measures with the Destre divided into 12 parts (figg. 4-5). At the moment, this operation is carried out to verify the method. Indeed, further study about measuring instruments used during the construction of the portals would be required to complete the dimensional study [23].

The geometrical analysis, conducted using the proportions of the rectangle, the golden triangle, and the relations between the sides of the rectangles, have given a rather interesting result. In both cases, the opening does not seem to be commensurate with the golden rectangle, while the golden triangle has only a gap of $11 \mathrm{~cm}$ in Ula Tirso and $4 \mathrm{~cm}$ in Sestu, (fig. 6). I have also found that the rectangle that includes the entire system, which is defined, vertically from the threshold and the ends of the arc, horizontally from the frame of the hoof (therefore including the entire opening and all the decorations) (fig. 7), respects the proportion 2:3 in both cases. It should be noted, in fact, that the vertical line through the outer part of the frame is tangent to the ends of the corbels which delimit the arc in the horizontal.

However, the differences may be negligible, considering that the precision of measuring and representation instruments, used to reconstruct the engineering practice differs greatly from those actually used by the builders. The method can then be verified by adding further examples.

\subsection{Study of the Block System}

In Sestu, the arch consists of seven blocks molded by hand, perfectly mirrored. The starting ashlar of the arc coincides with the first one of the lintel where there is the start of the molding of the straight frame.

The arc was thus conceived in order to fulfill discharge static functions above the lintel, while the eyebrow arch was a purely decorative element, consisting of from five segments, roughly the same size, on the right side, and from 6 ashlars with different sizes on the left side.

The lintel, consisting of three elements per side, including the impost ashlar, is a perfect mirror image of the keystone. The piers consist of ten elements per side. The height of the blocks varies from 26 to $36 \mathrm{~cm}$. The segments that are on the same course on opposite sides of the portal are not always the same height, which sometimes does not coincide with that of the stones of the masonry of the façade (fig. 8). The ashlar of the capital also contains the shelf and the start of the molding of the pier. Two blocks in the lower contain the base, and one another the start of the decoration of the molding.

\section{CHURCH OF SANTANDREA - ULA TIRSO}

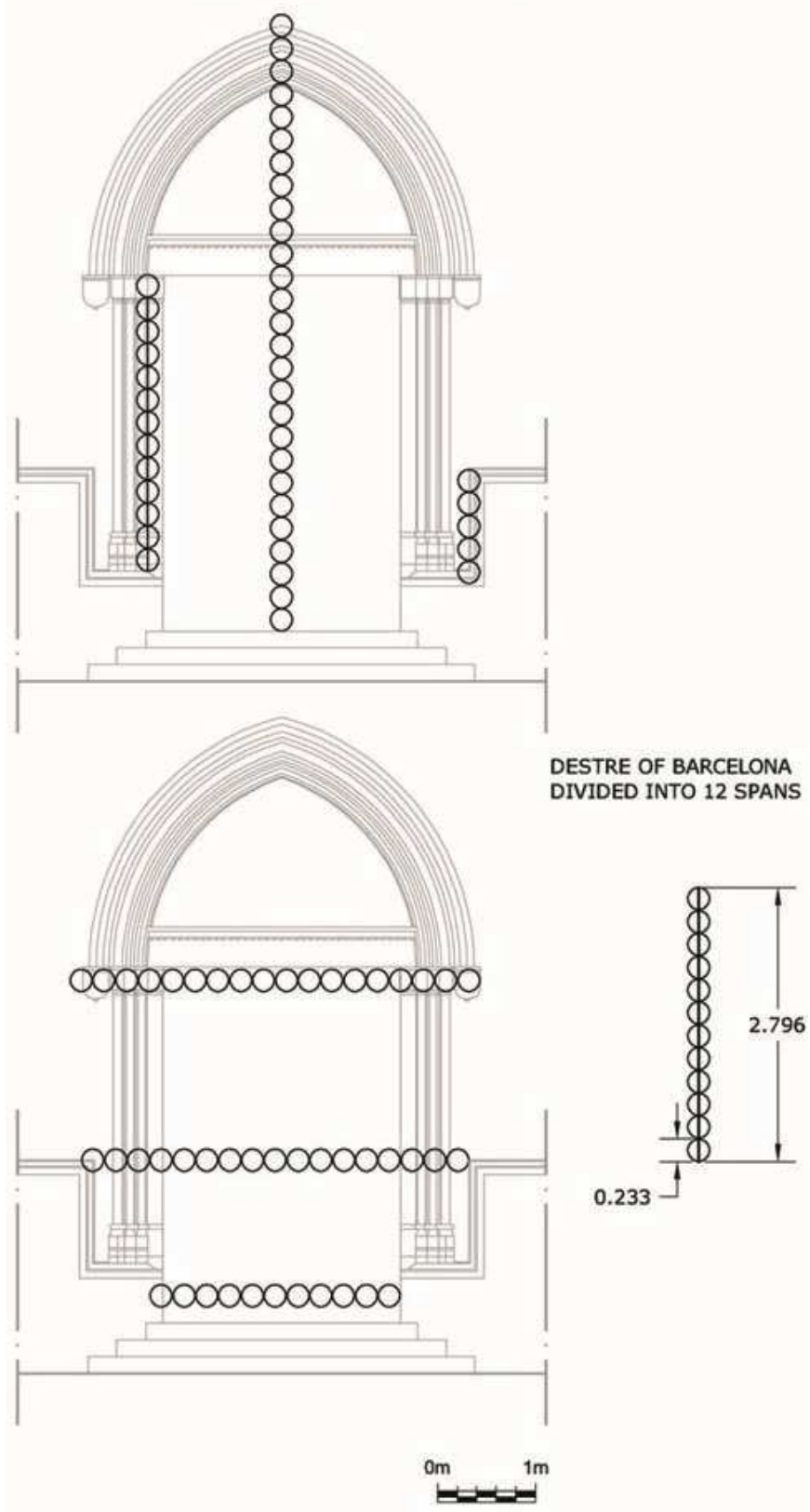

Fig -4: Dimension analysis with the "Destre of Barcelona" in the portal of Ula Tirso 
In Ula Tirso the arch consists of seven blocks molded by hand, perfectly mirrored. Also here, the starting ashlar of the arc coincides with the first one of the lintel where there is the start of the molding of the straight frame. Also in this case, the eyebrow arch has a decorative function and is composed of six segments per side. The lintel is identical in composition, to that of Sestu, with three elements per side in addition to the keystone. The piers consist of eleven elements per side. The height of the blocks varies from 26 to $36 \mathrm{~cm}$. Unlike Sestu, the ashlars that are on the same course on opposite sides of the portal, have the same height which coincides with that of the stones of the masonry of the façade.
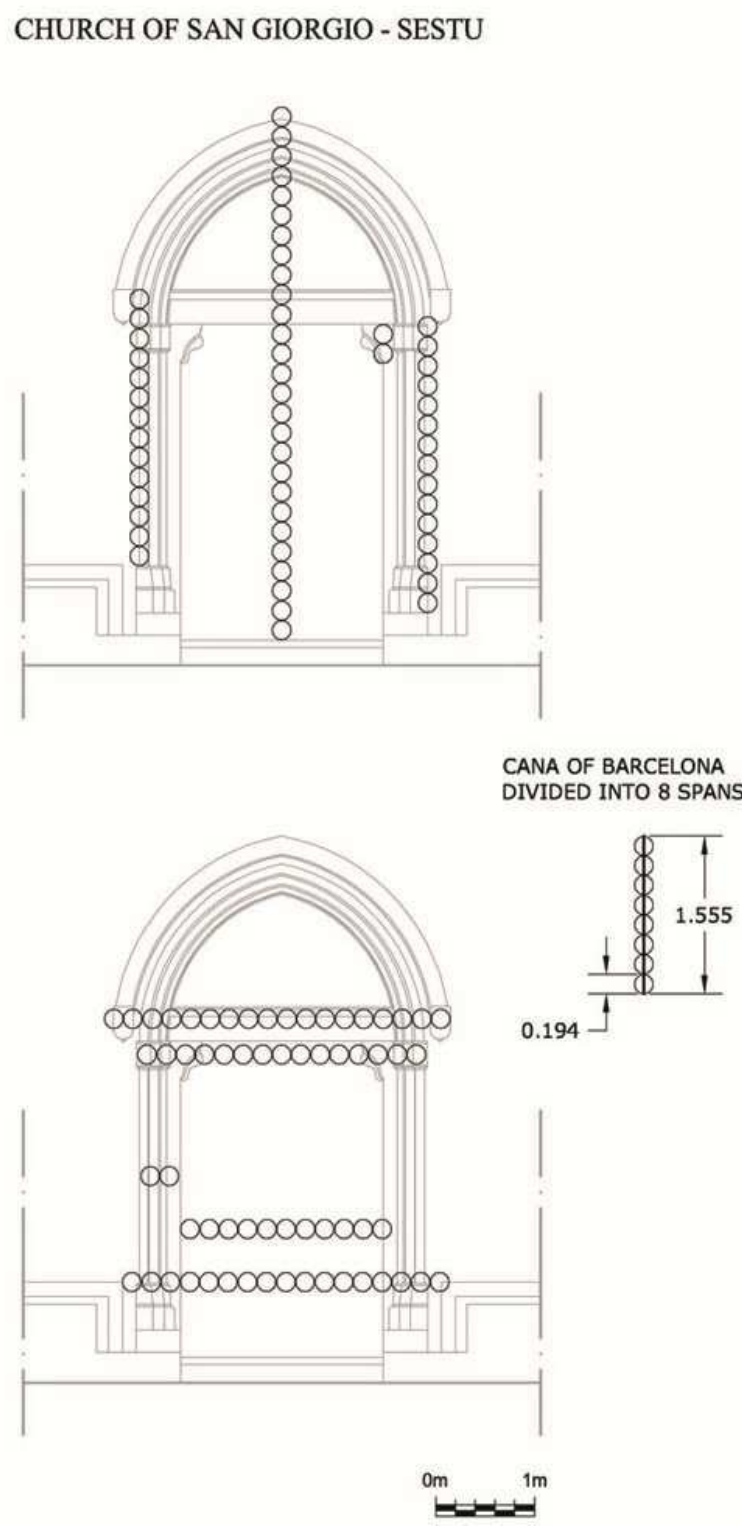

Fig -5: Dimension analysis with the "Destre of Barcelona" in the portal of Sestu
As in the case of Sestu, the ashlar of the capital also contains the start of the molding of the pier. In this case there is no shelf, but there is a square capital. Here too, two blocks in the lower contain the base, and one another the start of the decoration of the moulding. From the comparison, it can therefore be deduced that the number and position of the ashlars was governed by the laws of stereotomy. In addition, size of the individual blocks does not seem influenced by the type of material used. The analysis also shows that the connection ashlars were designed the same way in all analyzed cases.

\section{CHURCH OF SANTANDREA - ULA TIRSO}

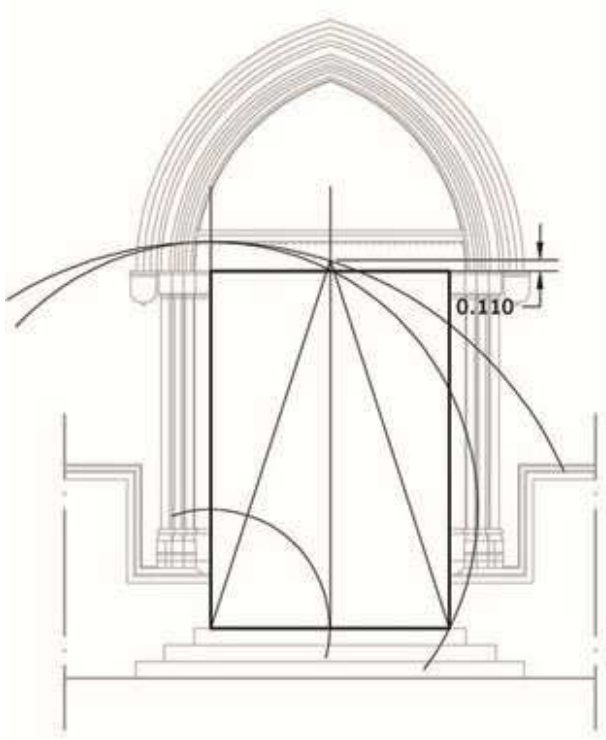

CHURCH OF SAN GIORGIO - SESTU

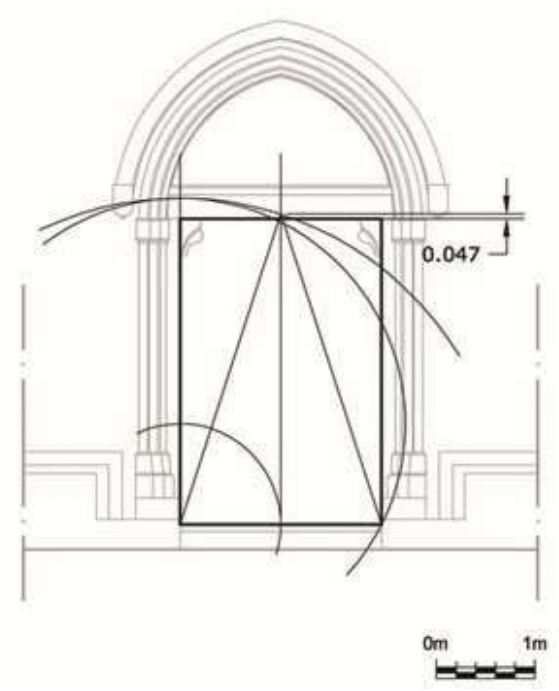

Fig -6: Study of proportion through the use of the golden triangle. 
CHURCH OF SANT'ANDREA - ULA TIRSO

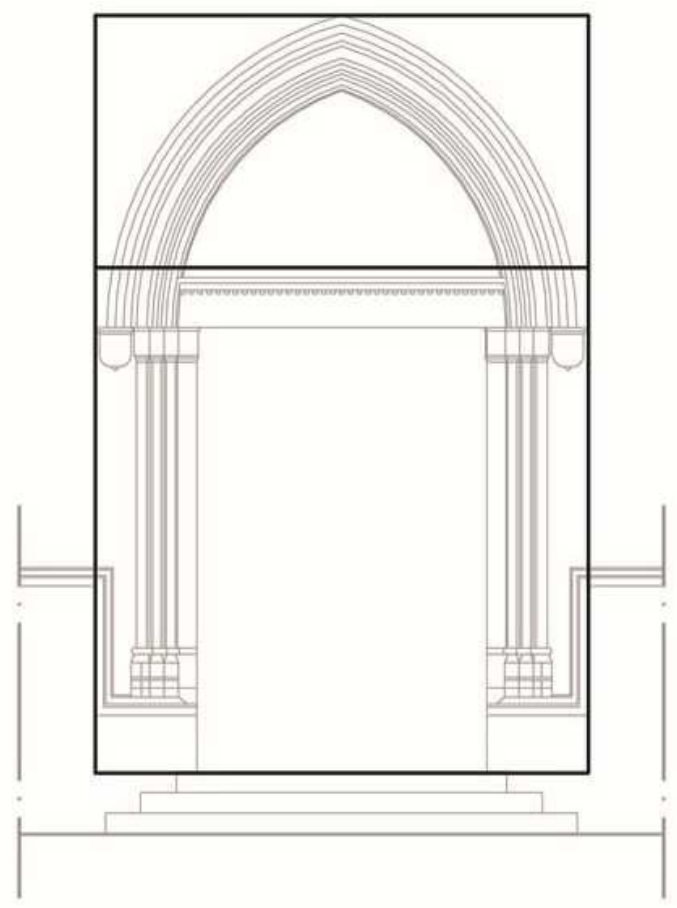

CHURCH OF SAN GIORGIO - SESTU

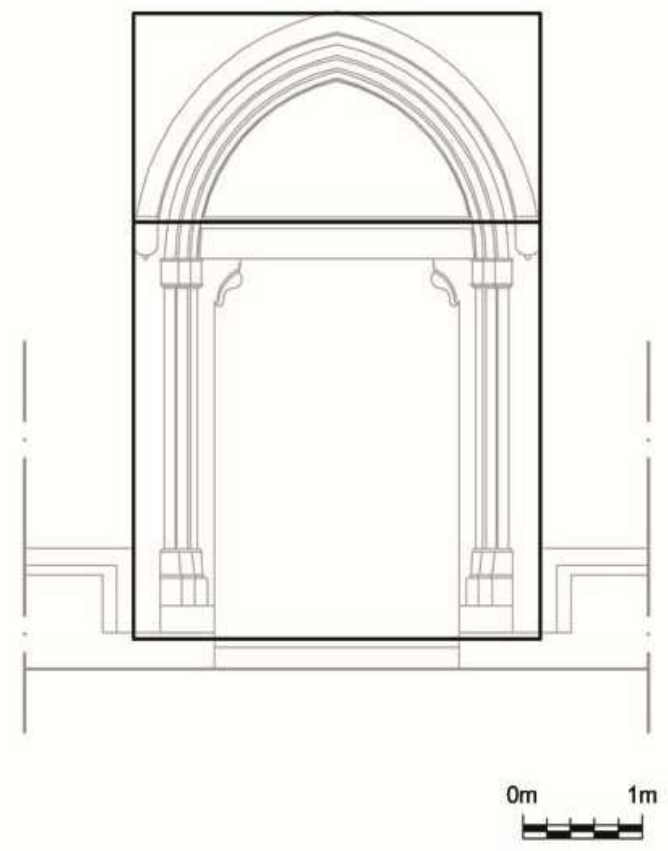

Fig -7: Representation of rectangle that includes the entire decoration system.

\section{CHURCH OF SANT'ANDREA - ULA TIRSO}

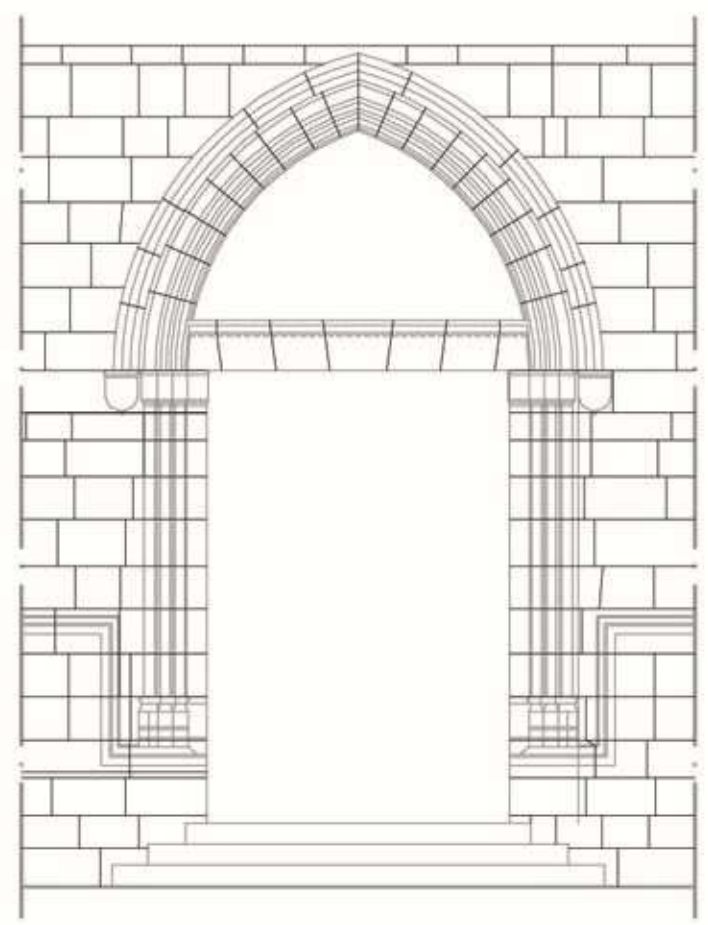

CHURCH OF SAN GIORGIO - SESTU

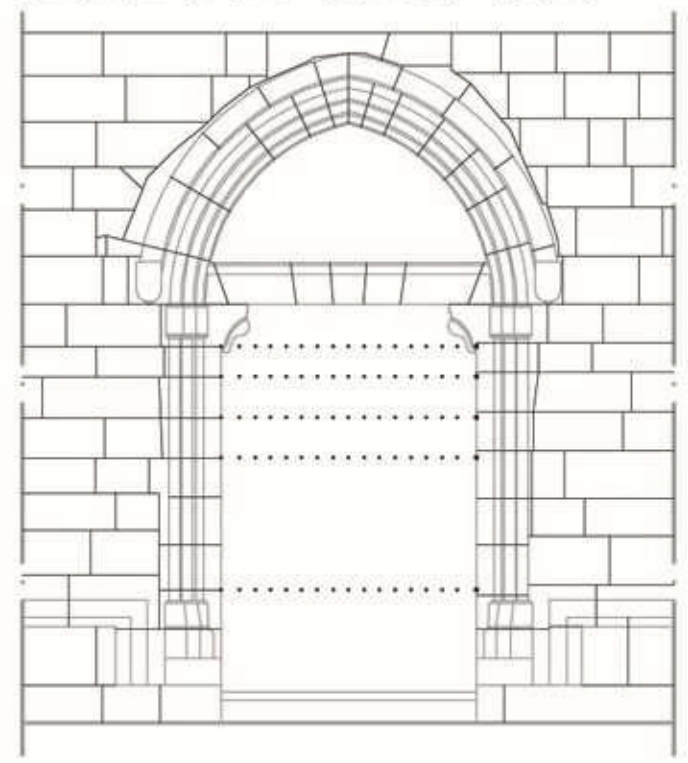

Om

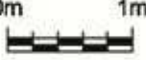

Fig -8: Study of the block system 


\section{CONCLUSIONS}

The proposed analysis system allowed to highlight the specificities of the cases analyzed. However, it is structured so that the application can be repeatable. Ultimately, the pattern of actions to be performed consists in:

- Direct Survey joined to a photo modeling procedure used as verification.

- Restitution of survey with schematization of the decorative elements.

- Analysis of the proportions, reporting relationships in a graphical way on the drawing and comparing them with known proportional system.

- Considerations on the units of measurement used by manufacturers and comparisons

- Survey on the arrangement and number of the blocks that make up the object.

In this way the study, performed on geometric and dimensional bases and closely related to the conservation status, gives complete information of each studied portal.

This kind of analysis allows objective verification, and becomes the starting point for comparisons of greater detail, using the same criteria, may take into account the individual sculpted ashlar and the sequence of moldings. The size of these ashlars and the succession of torus, cymas, scotias can then be related to the construction material.

In relation to the specific cases analyzed, I can say that the rules of construction are the same. The relations of proportion which have determined the composition of the portal are the same, even if the dimensions are different. However, it is clear that each portal has a constructive development bound to the material and the accuracy of the performers of the work. the geometric comparison is an important part of architecture's studies. For the full and complete understanding of historical architecture it is desirable to have a closer collaboration between drawing, geometry and history of art. This could allow an easier time location of the artifacts, even in the absence of documents to attest to their dating.

\section{REFERENCES}

[1]. Casu Paola, Pisu Claudia, (2012), Le volte nervate del tardogotico sardo, in DISEGNARECON Migliari Riccardo (a cura di). Vol 9, 2012.

[2]. Mira Eduardo, Zaragoza Catalàn Arturo (2003), Una Arquitectura gotica mediterranea. Comunidad valenciana, Catalogo de la Exposiciò. 2 vols. Valencia, Conselleria de Cultura y Educaciò.

[3]. Frankl Paul, (2000), Gothic Architecture, Yale University Press.

[4]. Cundari Cesare (editor) (2007), L'architettura di età aragonese nell'Italia centro-meridionale. Rapporto conclusivo. Vol. 9, Kappa Edizioni, Roma.

[5]. Pisu Claudia, (2010,. Virtual recostruction of a gothic window, in EGA 2010 - XIII International Congress of Architectural Graphic Expression, Valencia 27-28-29 maggio 2010, Actas volumen III CD rom, Editorial de la Universitat Politécnica de Valéncia, Valencia.

[6]. Segni Pulvirenti Francesca, Sari Aldo, (1994). Architettura tardogotica e d'influsso rinascimentale. Nuoro. Ilisso.

[7]. Serra Renata, (1966), Le parrocchiali di Assemini, Sestu e Settimo San Pietro. Note per una storia dell'architettura tardogotica in Sardegna. Atti del XIII Congresso di Storia dell'Architettura. Roma. 
[8]. Paola Casu, Claudia Pisu, Rilievo e analisi geometrica dei portali del Campidano di Cagliari, in APEGA 2010, $\mathrm{X}$ Congreso International de Expresión Gráfica aplicada al Edificatión, Libro de Actas, Universidad de Alicante Departemento de Expresión Gráfica y Cartografía, Editorial Marfil, Alicante 2010, pp.825-834.

[9]. Pisu Claudia, (2010), Geometric analysis of gothic openings with ogee arch, Proceedings of The 14th International Conference on Geometry and Graphics, Edited by International Society for Geometry and Graphics, Kyoto, 2010, P.352.

[10] Pisu Claudia, Casu Paola, (2013), Cloud GIS and 3d modelling to enhance sardinian late gothic architectural heritage, Int. Arch. Photogramm. Remote Sens. Spatial Inf. Sci., XL-5/W2, 489-494, doi:10.5194/isprsarchives-XL-5-W2489-2013, 2013.

[11]. Hembidge Jay, (1919), The elements of dynamic symmetry. Yale university press. 1919. p 133.

[12]. Docci Mario, Maestri Diego, (2009). Manuale di rilevamento architettonico e urbano. Nuova edizione ampliata 2009, Roma.

[13]. Galizia M, Santagati C. (2012), Architettura e/è Geometria: dalla forma architettonica alla costruzione geometrica. DISEGNARECON,. 5 (9): 135-144.

[14]. Gurgone Nino, Inglese Carlo, (2008), Del discrimine tra scienza e tecnica. Il rilievo dei mosaici dell'Accademia di Scherma al Foro Italico. Disegnare idee immagini. 2008, $\mathrm{n}^{\circ}$ 36, p. 60-71.

[15]. Paola Casu, Claudia Pisu, (2013), Photo-modeling and cloud computing. Applications in the survey of late gothic architectural elements, Int. Arch. Photogramm. Remote Sens. Spatial Inf. Sci., XL-5/W1, 2013, pp. 43-50, ISSN 1682-1750.

[16]. Marie Therese Zenner, (2002), Villard de Honnecourt and Euclidean Geometry, Nexus Network Journal, Number 2 / November 2002, pp. 65-78.

[17]. Inzerillo Laura, (2009), Elementi Architettonici Nei Paramenti Murari Tra XIV e XV Secolo. Il Rilievo Delle Bifore Del Castello Di Erice. in Metodi e tecniche integrate di rilevamento per la realizzazione di modelli virtuali dell' architettura della città, Roma, Gangemi.

[18]. Harrison Titeljorg, II (2002), How Should We Measure an Ancient Structure?, Nexus Network Journal, Number 2 / November 2002, pp. 14-20.

[19]. Padovan Richard, (2008), Proportion : science, philosophy, architecture. London, New York, Routledge.

[20]. Grillo Silvana, (2009), Manuale tematico della pietra, in "I Manuali di recupero dei centri storici della Sardegna", vol II -2 , Cagliari.

[21]. Real Orden de 9 de diciembre de 1852, por la que se determinan las tablas de correspondencia recíproca entre las pesas y medidas métricas y las actualmente en uso. Centro Éspañol de metrologia

[22]. Cavallo Giorgio, (2007), Due artisti marmorari lombardi attivi in Sardegna nei primi decenni del Settecento: Giovanni Pietro Angelo Fossati e Giuseppe Maria Massetti. La Valle Intelvi quaderno $\mathrm{n}^{\circ} 11,2006$. pp.11-57.

[23]. C. Caciagli, (2001), On Precision in Architecture, Nexus Network Journal, vol. 3, no. 1, (2001) pp. 11-15 


\section{BIOGRAPHY}

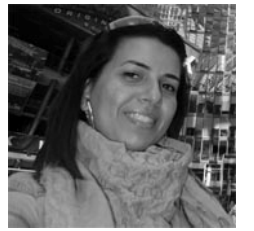

Claudia Pisu, engineer, $\mathrm{PhD}$ in Civil Engineering. Was Research Fellow at the Department of Engineering Civil, Environmental, Architecture, University of Cagliari. From 2008 she teaches Drawing in the Faculty of Architecture and Engineering at University of Cagliari. Conducts research in the field of computerized Representation Techniques, Digital Models for the analysis and visualization of Cultural Heritage of Surveying and Representation of Architecture. 